\title{
Evaluation of Household Pyrolitic Stove Performance: Effect of Bottom Air Apertures
}

\author{
Yano Surya Pradana ${ }^{\#}$, Muhamad Hartono ${ }^{*}$, Agus Prasetya ${ }^{\#}$

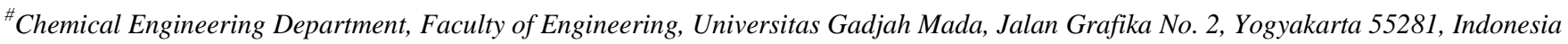 \\ E-mail:yanopradana@ugm.ac.id,aguspras@ugm.ac.id
}

*Chemical Engineering Department, Faculty of Applied Sciences, Delft University of Technology, Mekelweg 2, 2628 CD Delft, Netherlands E-mail:mhartono0307@gmail.com

\begin{abstract}
Nowadays, the global energy crisis has been encouraging the development of renewable energy. Biomass has emerged as one of the most attractive renewable energy sources in Indonesia. Compared with fossil fuels, biomass is available in abundant quantity, renewable, and non-toxic. Pyrolitic, a method to process biomass, was performed in a household cook stove (also known as a pyrolitic stove). The pyrolitic stove will be developed as an option for substituting traditional cook stove improve the thermal efficiency. In this study, the pyrolitic of twigs of Indonesian teak in the pyrolitic stove was investigated. The influence of bottom air apertures on the household pyrolitic stove performance was studied. It was found that the decreasing number of bottom air apertures resulted in a longer leg-phase of temperature change, higher char yield, lower ash yield, and energy recovery. However, the temperature change was only slightly affected by one-third open outer air apertures condition. According to the condition performed in this study, 60 bottom air apertures in the stove provided an optimum energy recovery for cooking.
\end{abstract}

Keywords - renewable energy; biomass; teak; pyrolitic stove; bottom air aperture

\section{INTRODUCTION}

Biomass is a potential natural resource spread all over the world. In tropical countries, its availability is very abundant, and it takes an important role to meet the needs of people [1]. Energy conversion is one of the top concerned issues for utilizing biomass surrounded by increasing energy consumption and fossil fuel depletion [2]. Developing energy and energy supports from biomass gives new spirit providing sustainability of feedstock, non-toxicity of products and environmental friendly [3], [4]. The use of biomass-derived fuels also keeps the carbon cycle in the atmosphere, zero-carbon accumulation, which is reducing global climate change effects [5]. To support this concept, management of biomass availability has to be created, i.e., in the forest [6] and municipal solid waste [7].

Historically, biomass has been used as fuel, which is still limited to the traditional way of using cook stove. Biomass combustion in traditional cook stove is identically inefficient and incomplete, generating hazardous gaseous and particulate matter emissions [8]. They have an impact on the health of exposed people, especially in indoor condition. The hazardous gaseous emitted from incomplete burning, such as carbon monoxide $(\mathrm{CO})$, are firmly causing several diseases related to cardiovascular and pulmonary [9]. Then, the particulate matter will disrupt human respiratory system [10], causing many people to die per year [11].

Household pyrolitic stove is developed as an option for substituting traditional cook stove. This proposed stove is expected to optimize biomass pyrolitic to increase thermal efficiency and completion of biomass burning. Before combustion process, organic material in biomass is decomposed thermally to convert solid-form hydrocarbon into the liquid-form hydrocarbon, called pyrolitic [12]. This process will be followed by gasification, which is producing gaseous products [13], such as hydrogen, carbon monoxide, methane, and carbon dioxide. They are then entirely burned force more heat extraction from biomass.

One of simple household pyrolitic stove design is illustrated in Fig. 1. Categorized into TLUD (Top-Lit Updraft) gasified configuration, this stove consists of one inner cylinder and one outer cylinder. Combustion and pyrolitic of biomass are performed inside the inner cylinder. During pyrolitic, oxygen is supplied from primary air apertures (holes) under the limited condition to ensure oxygen supply, besides preventing more combustion. Furthermore, oxygen is also needed for burning gaseous products in the secondary air apertures.

Evaluation of the household pyrolitic stove performance is done by investigating the variables influencing heat 
extraction of biomass in a pyrolitic stove. In this study, the influence of bottom air apertures on the pyrolitic process was studied. Improvement of the thermal efficiency of the stove was achieved by optimizing the energy recovery for cooking. Biomass used as feedstock was twig of teak from Yogyakarta, which is one of residue from teak cultivation.

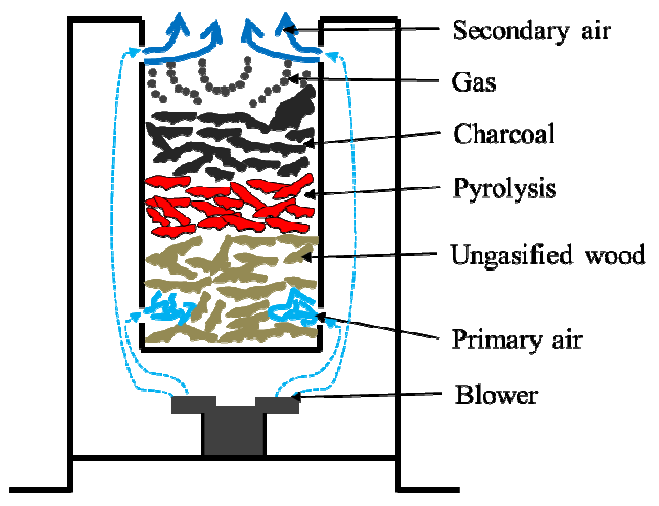

Fig. 1 Design of household pyrolitic stove

\section{MATERIALS AND METHODS}

\section{A. Materials}

The material used as a feedstock was twigs of teak from Wonosari, Yogyakarta, Indonesia. The average twig diameter of $1.9219 \mathrm{~cm}$, which was distributed as in Table 1, was sliced in $6 \mathrm{~cm}$ length. After cutting process, the water in the sliced twig was removed by drying it at a temperature of $110{ }^{\circ} \mathrm{C}$ in the oven to obtain constant mass. It was then stored in the closed container at room temperature. The sample of the twig was analyzed by a proximate and ultimate method to characterize the feedstocks. Kerosene as burning initiator was obtained from PT. Pertamina. Water for measuring thermal efficiency was obtained from the Chemical Engineering Department, Universitas Gadjah Mada.

TABLE I

SIZE DISTRIBUTION OF TWIG SAMPLE

\begin{tabular}{|c|r|r|r|}
\hline $\begin{array}{c}\text { Mean } \\
\text { diameter, cm }\end{array}$ & Mass, g & $\begin{array}{c}\text { Mass } \\
\text { fraction }\end{array}$ & $\begin{array}{c}\text { Mean diameter } \\
\text { x Mass fraction }\end{array}$ \\
\hline 1.6 & $4,533.84$ & 0.2061 & 0.3298 \\
\hline 1.9 & $11,322.54$ & 0.5148 & 0.9781 \\
\hline 2.2 & $6,138.54$ & 0.2791 & 0.6140 \\
\hline Total & $21,994.92$ & 1.0000 & 1.9219 \\
\hline $\begin{array}{l}\text { Average } \\
\text { diameter, cm }\end{array}$ & & & \\
\hline
\end{tabular}

Note: measured in the wet condition

\section{B. Methods}

All performance tests were conducted in $20 \mathrm{~cm} \mathrm{x} 40 \mathrm{~cm}$ (diameter $\mathrm{x}$ height) stove, as shown in Fig. 2, at Energy Conservation and Pollution Prevention Laboratory, Chemical Engineering Department, Universitas Gadjah Mada. This stove applies natural airflow, without a fan in the bottom, through outer air apertures. Then, the airflows toward primary air apertures (diameter of 3/4 in. per aperture), bottom air apertures (diameter of $1 / 16$ in. per aperture), and secondary air apertures (diameter of 1/4 in. per aperture). Parameter evaluated in this paper was bottom air apertures with various numbers of 60,18 and 0 apertures. The experiment was repeated by three times. Prepared twig sample of 750 grams $\left(\mathrm{m}_{0}\right)$ was fed into pyrolitic stove and thermocouple was placed to reach the wall of inner cylinder for measuring temperature.
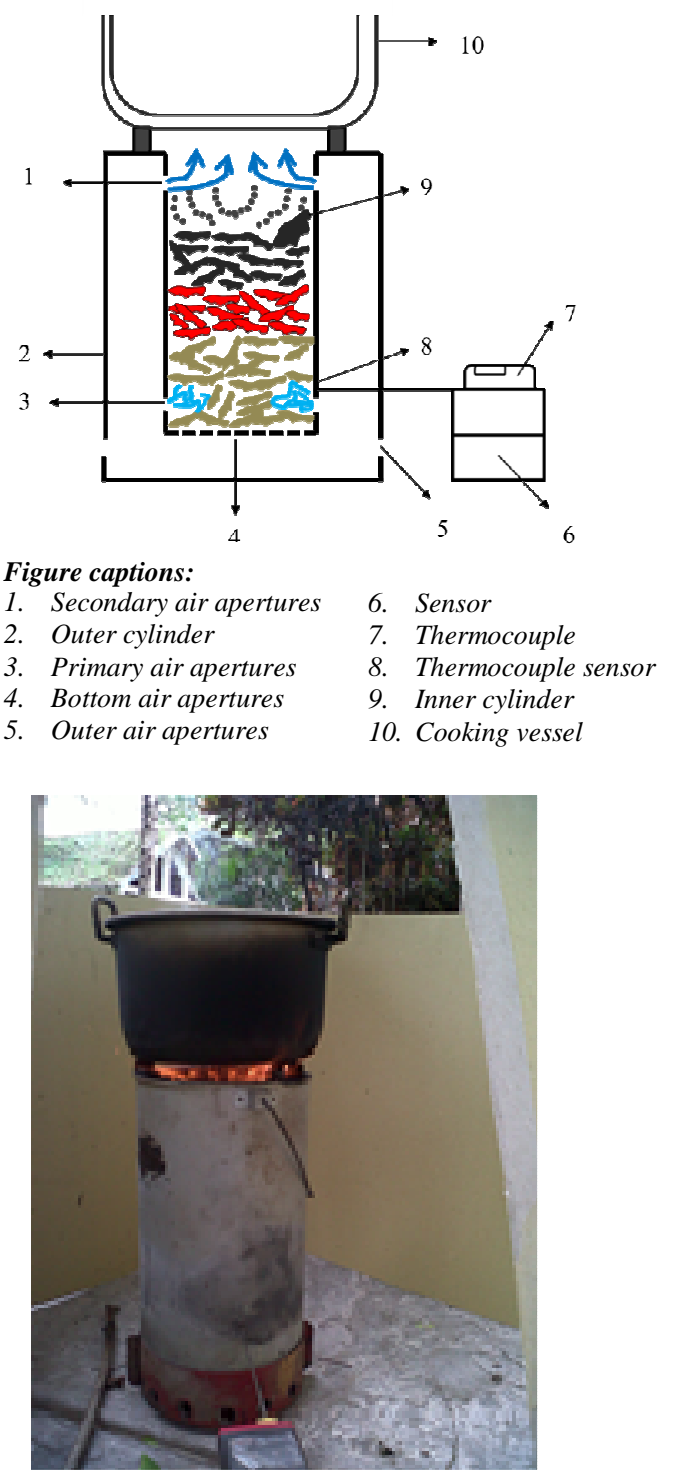

Fig. 2 Equipment setting of the pyrolitic stove

Kerosene was given into the biomass sample, and the burning was initiated. Kerosene was still put gradually to stabilize combustion. Initial time $\left(\mathrm{t}_{0}\right)$ and initial temperature $\left(\mathrm{T}_{0}\right)$ was determined after the combustion was stable without additional kerosene, as shown in Fig. 3. On the top of the stove, a pan containing 1 liter of water $\left(\mathrm{V}_{0}\right)$ and thermometer were prepared. The temperature of the inner cylinder wall was noted every 2.5 minutes for 45 minutes. After the fire was going out $\left(\mathrm{t}_{\text {end }}\right)$, the remaining volume of water, the temperature of water, the remaining mass of charcoal and ash was noted as $\mathrm{V}_{\text {end }}, \mathrm{T}_{\text {end }}, \mathrm{m}_{\text {char }}$ and $\mathrm{m}_{\text {ash }}$, respectively. Energy recovery for cooking $\left(\mathrm{E}_{\mathrm{cook}}\right)$ was calculated by using Equation 1 [14]: 


$$
E_{\text {cook }}=\frac{\left\lfloor\rho V_{0} c_{p}\left(T_{0}-T_{\text {end }}\right)+\rho\left(V_{0}-V_{\text {end }}\right) \Delta H_{v}\right\rfloor}{m_{0}}
$$

The percentage of energy recovery for cooking was then approximated by comparing it with total combustion energy of volatile matter composition as methane. Standard enthalpy of combustion of methane was $-890.4 \mathrm{~kJ} / \mathrm{mol}$ (equal with $-13,356 \mathrm{cal} / \mathrm{g}$ ) [15].
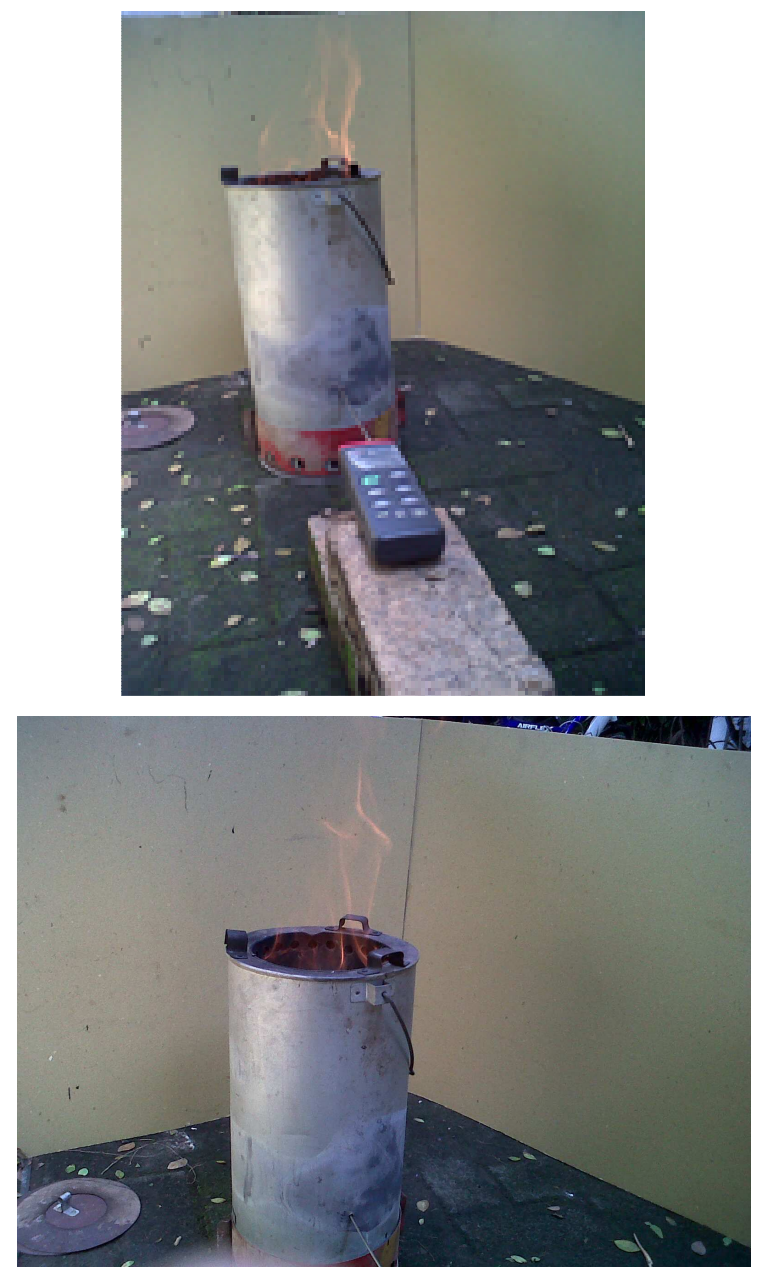

Fig. 3 Fire condition at the initial time $\left(\mathrm{t}_{0}\right)$ and initial temperature $\left(\mathrm{T}_{0}\right)$

\section{RESULTS AND DISCUSSION}

\section{A. Biomass Characterization}

To evaluate the compositions and properties, the dry twig of Indonesian teak sample, an elemental and proximate analysis was performed. The proximate analysis estimates the volatile matter, moisture, ash content, and char content whereas elemental (ultimate) analysis determines the elemental composition, such as $\mathrm{O}, \mathrm{H}, \mathrm{N}$, S, et cetera. The results of the proximate and ultimate analysis for the teak sample used in this study were presented in Table 2. From Table 2, a high volatile matter content in teak samples (77.58 \%wt) expressed high, released part of samples in the form of gases during the thermal process. This released part was then mixed with air and burned for converting it into energy directly by combustion or by a thermal process indirectly.

TABLE II

ElEMENTAL AND PROXIMATE ANALYSIS RESUlts FOR DRY TwIGS OF INDONESIAN TEAK [14]

\begin{tabular}{|l|r|}
\hline Elemental analysis* & Composition, \%wt \\
\hline Carbon $(\mathrm{C})$ & 48.70 \\
\hline Oxygen $(\mathrm{O})$ & 44.12 \\
\hline Hydrogen $(\mathrm{H})$ & 6.40 \\
\hline Nitrogen $(\mathrm{N})$ & 0.78 \\
\hline Sulfur $(\mathrm{S})$ & (trace) \\
\hline Proximate analysis & \\
\hline Volatile matter & 77.58 \\
\hline Water & 10.55 \\
\hline Char & 10.68 \\
\hline Ash & 1.19 \\
\hline$*$ Dry-ash free &
\end{tabular}

The thermal process also produced a solid by-product, namely char, and ash. Char was composed of fixed carbon, while ash was composed of inorganic matter in biomass sample [16]. A sample of teak had a lower trend on char and ash composition than other biomass. As a comparison, cornstalk and Chlorella sp. had char composition of $16.65 \% \mathrm{wt}$ and $15.42 \% \mathrm{wt}$, respectively, and ash composition of $7.15 \%$ wt and $6.48 \% \mathrm{wt}$, respectively [17].

Dry biomass also had a moisture content, which expressed the quantity of water in mass unit per mass of dry biomass sample that cannot be removed after the convection drying process. Compared to cornstalk and Chlorella sp. [17], the teak sample had a higher moisture content. During the thermal process, the moisture content will take energy for transforming into gas, thus reducing the heating value of biomass.

Furthermore, biomass characteristics from the ultimate analysis will specify raw materials efficacy as a fuel or other functions. The component compositions of the sample were almost the same as wood stem [16]. This composition refers the suitable efficacy of sample as fuel because of high carbon content and low sulfur content. The energy conversion from low sulfur content resources will promote in reducing acid rain effect.

\section{B. Temperature Change}

The measured inner cylinder temperatures correlated with time during heat extraction process in the stove are presented in Fig. 4. Temperature trend showed the log-phase in the early time, log-phase reaching peak temperature in the mid time range and cooling-phase at the end of the time range. Initial energy from initial biomass combustion was used to remove water content in biomass in the log-phase. In the log-phase, the temperature was rising quickly, and biomass was dominantly pyrolized. In cooling-phase, the temperature was then decreasing and isolation from the air prevented in char burning [14]. 


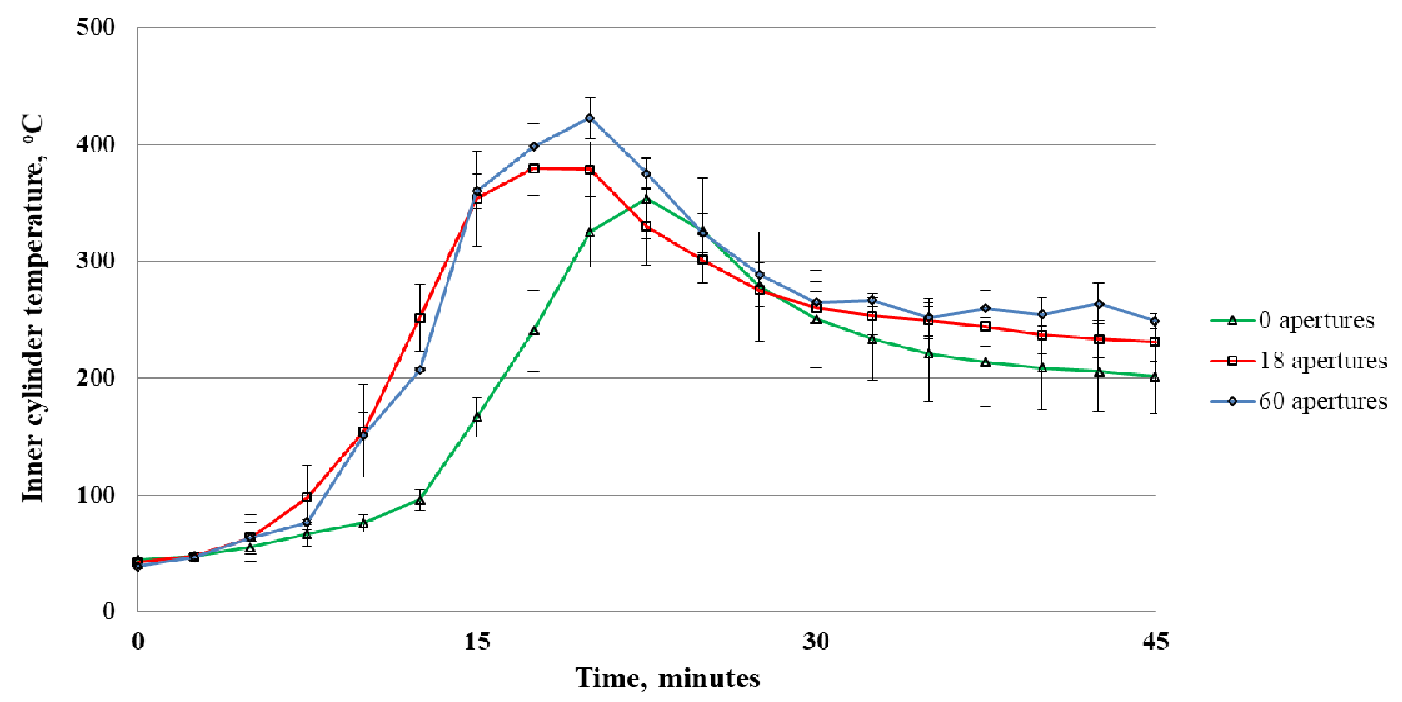

(a)

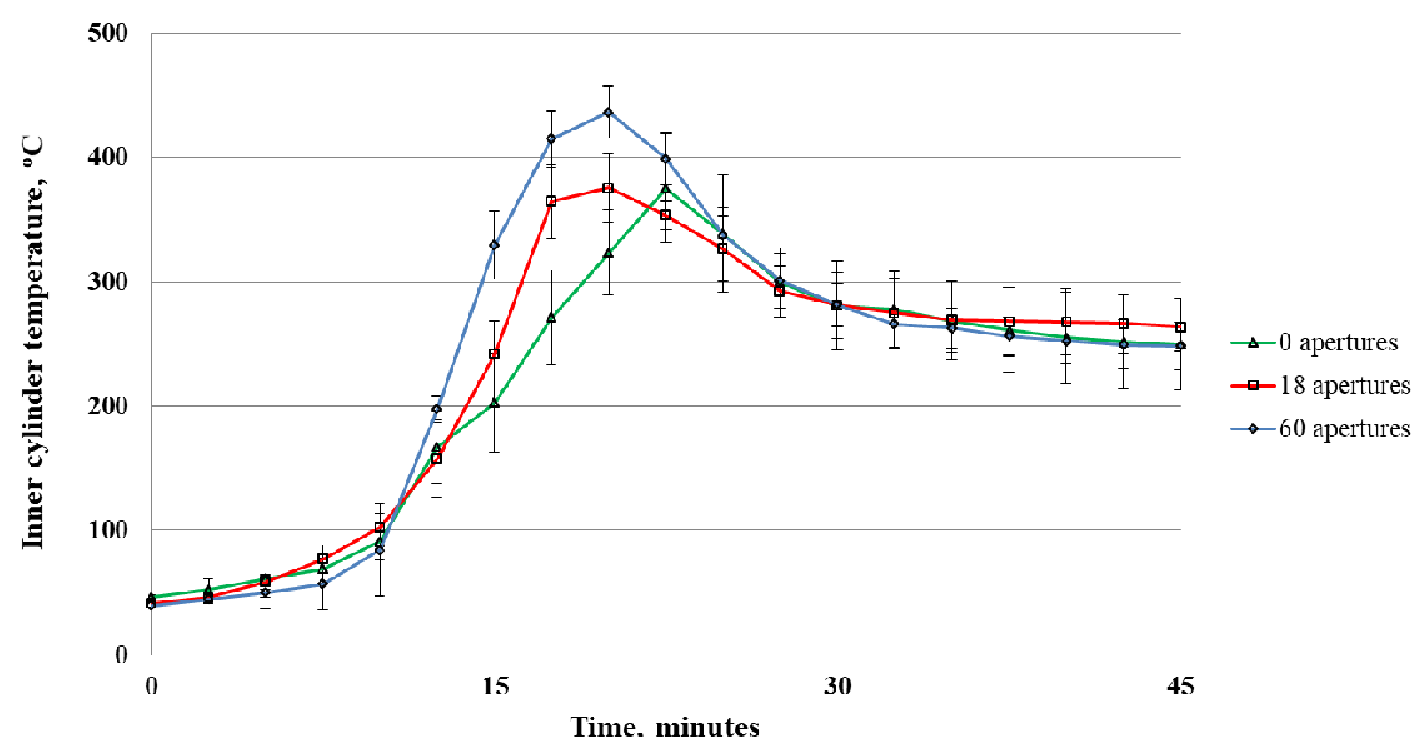

(b)

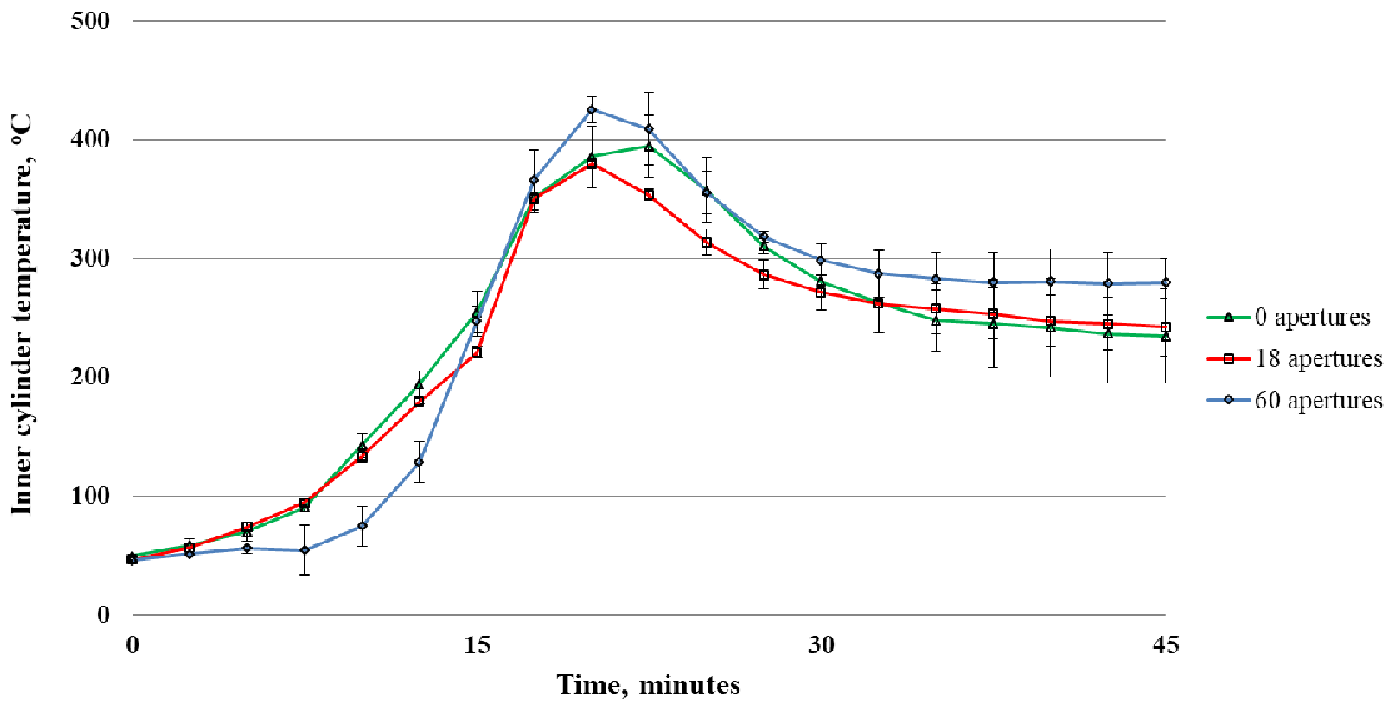

(c)

Fig. 4 Effect of bottom air apertures on the inner cylinder temperature: (a) fully open apertures; (b) 2/3 open apertures; (c) 1/3 open apertures 
As shown in Fig. 4(a), the differences in temperature change in inner cylinder in bottom air apertures of 60 and 18 are insignificant when outer air apertures are fully open. On the other hand, no bottom air aperture would influence legphase of temperature change. This case required longer initial biomass heating than the results of 60 and 18 bottom air apertures. No bottom air aperture would reduce air supply in the stove and limit the combustion of biomass, resulting in limitation of energy to vaporize moisture and obtain pyrolitic phase.

When the outer air apertures were $2 / 3$ open, as shown in Fig. 4(b), a slightly different trend of zero and 18 bottom air apertures was observed. Meanwhile, the trend of $\Delta \mathrm{T}$ graph of 18 and 60 apertures was significantly different. The peak point of 18 bottom air apertures was $376{ }^{\circ} \mathrm{C}$, with an error value of $\pm 27.4{ }^{\circ} \mathrm{C}$, and the peak point of 60 bottom air apertures was $437{ }^{\circ} \mathrm{C}$, with an error value of $\pm 21.0^{\circ} \mathrm{C}$. The error bar of each variable of bottom air apertures that represented the deviation of temperature measurement at any time during pyrolitic stove operation.

On the other hand, as shown in Figure. 4(c), 1/3 open outer air apertures show the slight different trend, including error bar consideration, in all variable of bottom air apertures. The results indicated that the temperature change of stove was only slightly affected by bottom air apertures. Moreover, the minimum air supply from the atmosphere caused the minimum distribution of air in the stove, which was tending to the same graphics flow. Thus, at any condition of outer air apertures, 60 bottom air apertures achieved the optimum condition. However, the observation of other parameters was needed to ensure the conclusion of bottom air apertures effect.

\section{Total Time of Fire}

Total time of the fire was described as the length of fire from secondary air apertures. It was calculated by finding the time from measured the initial time $\left(\mathrm{t}_{0}\right)$ to the final measured time $\left(\mathrm{t}_{\text {end }}\right)$. As can be seen in Figure 5, under any condition of outer air apertures, the total time of fire slightly decreased when the number of bottom air apertures was increased. The higher number of bottom air apertures increases the pyrolitic and rapid oxidation, which leads to faster fire distribution. However, the deviation value of the total time of the fire at any number of bottom air apertures and any outer air apertures condition was very high. It was suggested that the fired length in the pyrolitic stove was unpredictable and its control was also complicated. Thus, the optimum condition of pyrolitic stove operation was determined by evaluating other parameters, such as solid byproduct formation and energy recovery.

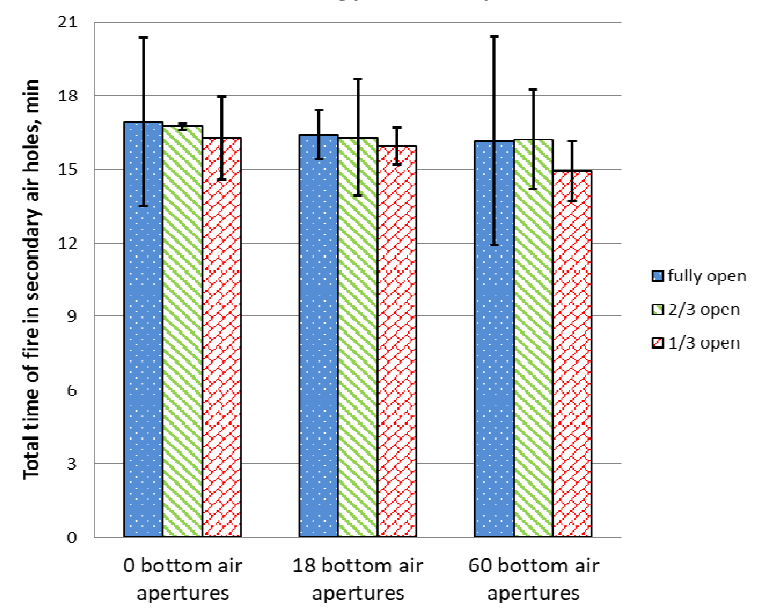

Fig. 5 Total time of fire of three different number of bottom air apertures

\section{Solid By-product Yield}

The solid by-product is one of the parameters to evaluate the performance of this stove. Fig. 6 illustrates the influence of the number of bottom air apertures on solid by-product yield, char (a) and ash (b) yield. It is indicated that as the number of bottom air apertures decreased, the char yield increased. More bottom air apertures would supply more oxygen in the air to pyrolitic and oxidize biomass rapidly, causing this phenomenon. Otherwise, the trend of ash yield was declining with the decreasing in the number of bottom air apertures. Combustion of solid fuel, besides organic matter, would also react inorganic matter with oxygen to generate inorganic oxide in the form of ash. Thus, the formation of ash was inversely proportional to char formation, which is directly proportional to the combustion process.

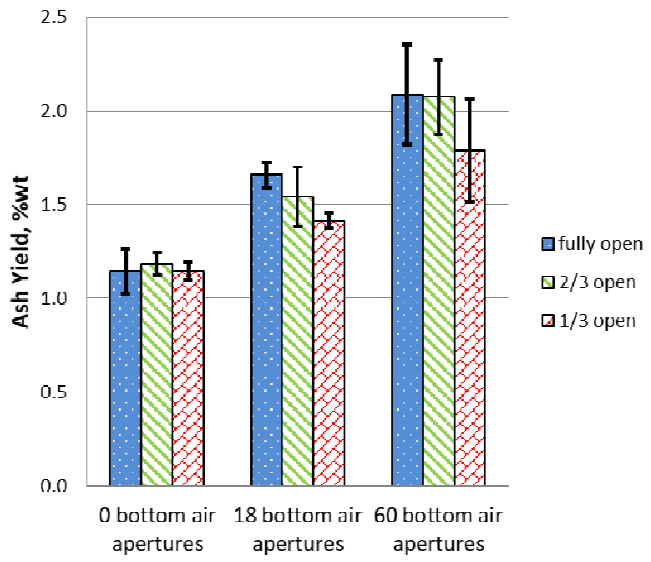

(b)

Fig. 6 Effect of bottom air apertures on a) char; (b) ash 


\section{E. Energy Recovery}

The effect of bottom air apertures on the energy recovery for cooking $\left(\mathrm{E}_{\mathrm{cook}}\right)$ is presented in Fig. 6, representing the total of sensible and vaporization heat of water in the pan. The optimum cooking energy recovery was $489.54 \mathrm{kcal} / \mathrm{kg}$ biomass at 60 bottom air apertures and fully open outer air apertures. From the value of energy recovery in Fig. 7, the percentage of energy recovery was then estimated by comparing with total combustion energy of volatile matter as methane, shown in Fig. 8. The average percentage of energy recovery was still very low $(4.01 \%)$ and raising by supplying more air into the inner cylinder.

Energy recovery was directly correlated with the combustion process. One of the essential factors was oxygen availability, promoting complete combustion of fuel, lowering char yield, raising ash yield and energy recovery. However, the results indicated a slight relation to a temperature change of inner cylinder, which was influenced by the distribution of air.

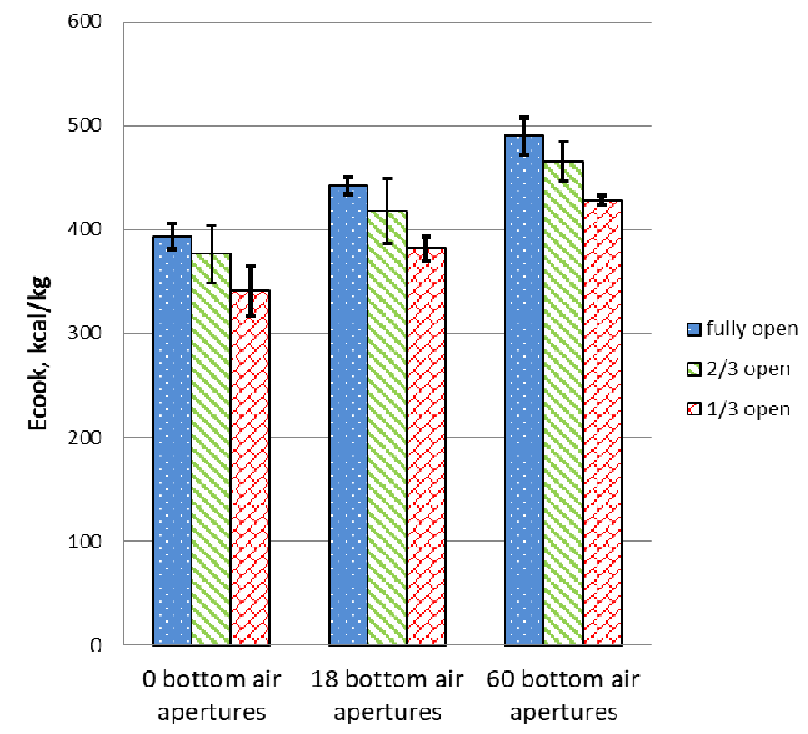

Fig. 7 Effect of bottom air apertures on cooking energy recovery

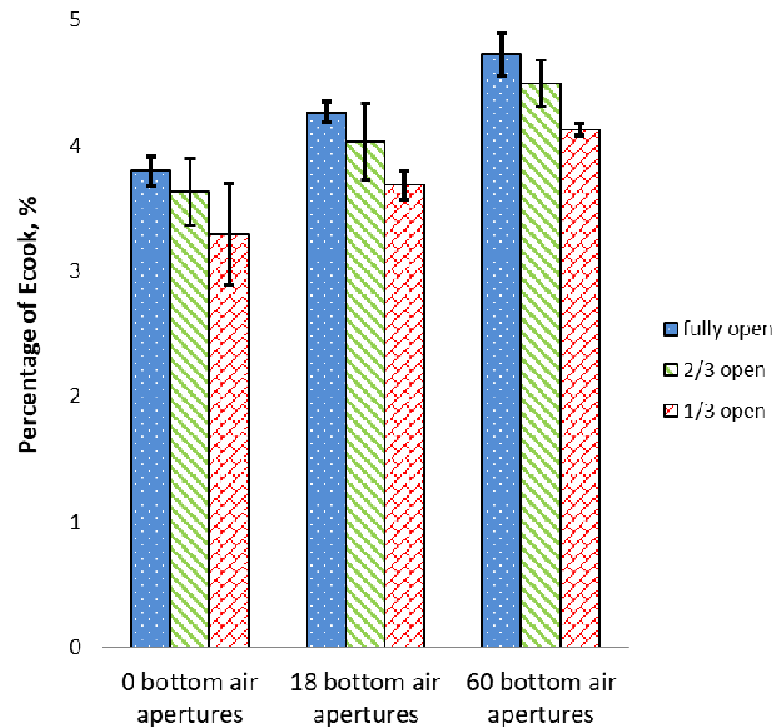

Fig. 8 Effect of bottom air apertures on the percentage of cooking energy recovery

\section{CONCLUSION}

The performance of pyrolitic stove associated with bottom air apertures effect was reported in this paper. The decreasing in the number of bottom air apertures correlated with reducing of oxygen supply and distribution in the stove. These phenomena would affect the longer leg-phase of temperature change, higher char yield, lower ash yield, and energy recovery. However, temperature change in the condition of one-third open outer air apertures indicated only a slight effect of bottom air apertures because of the minimum distribution of air in the stove. Furthermore, it was found that 60 bottom air apertures provided the maximum energy recovery for cooking.

\section{NOMENCLATURE}

$\begin{array}{lll}\mathrm{c}_{\mathrm{p}} & \text { Specific heat of water } & \mathrm{kcal} /(\mathrm{kg} \\ \mathrm{E}_{\mathrm{cook}} & \text { Energy recovery for cooking } & \mathrm{kcal} / \mathrm{kg} \\ \mathrm{m}_{0} & \text { Initial mass of twig sample } & \mathrm{kg} \\ \mathrm{m}_{\text {char }} & \text { Remaining mass of charcoal } & \mathrm{kg} \\ \mathrm{m}_{\text {ash }} & \text { Remaining mass of ash } & \mathrm{kg} \\ \mathrm{T}_{0} & \text { Initial temperature } & { }^{\circ} \mathrm{C} \\ \mathrm{T}_{\text {end }} & \text { Final temperature } & { }^{\circ} \mathrm{C} \\ \mathrm{t}_{0} & \text { Initial time } & \mathrm{min} \\ \mathrm{t}_{\text {end }} & \text { Final time } & \mathrm{min} \\ & & \\ \mathrm{V}_{0} & \text { Initial volume of water } & \mathrm{m}^{3} \\ \mathrm{~V}_{\text {end }} & \text { Remaining volume of water } & \mathrm{m}^{3} \\ & & \\ \mathrm{Greek} & \text { letters } & \mathrm{kg} / \mathrm{m}^{3} \\ \rho & \text { water density } & \mathrm{kcal} / \mathrm{kg} \\ \Delta \mathrm{H}_{\mathrm{v}} & \text { vaporization enthalpy change of water }\end{array}$

\section{ACKNOWLEDGEMENT}

Chemical Engineering Department, Universitas Gadjah Mada, primarily funded this project. The authors also gratefully acknowledge the funding from USAID through the SHERA program - Centre for Development of Sustainable Region (CDSR).

\section{REFERENCES}

[1] S. Wang, H. Lin, B. Ru, G. Dai, X. Wang, G. Xiao, and Z. Luo, "Kinetic modelling of biomass components pyrolitic using a sequential and coupling method "“Fuel, 2016, vol. 185, pp. 763-771.

[2] H. Dewajani, Rochmadi, S. Purwono, and A. Budiman, "Catalytic cracking of Indonesian Nyamplung oil (Calophyllum inophyllum) for bio-fuels production using ZSM-5 catalyst," Journal of Engineering Science and Technology, 2015, vol. 10 spec.issue. 7, pp. 61-69.

[3] Daniyanto, Sutijan, Deendarlianto and A. Budiman, "Reaction kinetic pyrolitic in mechanism of pyrolitic-gasification process of dry torrified-sugarcane bagasse," ARPN Journal of Engineering and Applied Sciences, 2016, vol. 11 no. 16, pp. 9974-9980.

[4] Y.S. Pradana, A. Hidayat, A. Prasetya and A. Budiman, "Application of coconut-shell activated carbon as heterogeneous solid catalyst for biodiesel synthesis," Defect and Diffusion Forum, 2018, vol. 382, pp. 280-285.

[5] B. Brandelet, C. Rose, C. Rogaume, and Y. Rogaume, "Investigation of the organic carbon ratio analysis on particles from biomass combustion and its evolution in three generations of firewood stoves," Biomass and Bioenergy, 2017, vol. 99, pp. 106-115.

[6] V. Leban, S.P. Malovrh, L.Z. Stirn and J. Krc, "Forest biomass for energy in multi-functional forest management: Insight into the perceptions of forest-related professionals," Forest Policy and Economics, 2016, vol 71, pp. 87-93. 
[7] H. Sudibyo, Y.S. Pradana, A. Budiman and W. Budhijanto, "Municipal Solid Waste Management in Indonesia - A study about selection of proper solid waste reduction method in D.I. Yogyakarta Province," Energy Procedia, 2017, vol. 143, pp. 494-499.

[8] C. L'orange, J. Volckens, and M. DeFoort, "Influence of stove type and cooking pot temperature on particulate matter emissions from biomass cook stoves," Energy for Sustainable Development, 2012, vol. 16, pp. 448-455.

[9] R. Suresh, V.K. Singh, J.K. Malik, A. Datta, R.C. Pal, "Evaluation of the performance of improved biomass cooking stoves with different solid biomass fuel types," Biomass and Bioenergy, 2016, vol. 95, pp. 27-34.

[10] M.M. Roy, and K.W. Corscadden, "An experimental study of combustion and emissions of biomass briquettes in a domestic wood stove," Applied Energy, 2012, vol. 99, pp. 206-212.

[11] M. Gallagher, M. Beard, M.J. Clifford, M.C. Watson, "An evaluation of a biomass stove safety protocol used for testing household cookstoves, in low and middle-income countries," Energy for Sustainable Development, 2016, vol. 33, pp. 14-25.

[12] Y.S. Pradana, A. Kurniawan, A, and A. Budiman, (2014). "Bio-oil Derived from Indonesian Oil Palm Empty Fruit Bunch (EFB) using
Middle-scale Slow Pyrolitic," in The International Oil Palm Conference, 2014, Bali, Indonesia.

[13] H. Sudibyo, A.I. Majid, Y.S. Pradana, W. Budhijanto, Deendarlianto, and A. Budiman, “Technological Evaluation of Municipal Solid Waste Management System in Indonesia," Energy Procedia, 2017, vol. 105, pp. 263-269.

[14] Y.S. Pradana, and A. Prasetya, "Performance evaluation of household pyrolytic stove: Effect of outer air apertures condition," in AIP Conference Proceedings, 2017, vol. 1823, art. no. 020069.

[15] D.M. Himmelblau, Basic Principles and Calculations in Chemical Engineering, 6th ed., Prentice-Hall International, Inc., 1996.

[16] Y.D. Singh, P. Mahanta, and U. Bora, "Comprehensive characterization of lignocellulosic biomass through proximate, ultimate and compositional analysis for bioenergy production," Renewable Energy, 2017, vol. 103, pp. 490-500.

[17] K. Li, L. Zhang, L. Zhu, and X. Zhu, "Comparative study on pyrolitic of lignocellulosic and algal biomass using pyrolitic-gas chromatography/mass spectrometry," Bioresource Technology, 2017, vol. 234 , pp. $48-52$. 